\title{
Step into the Future: Bigness and Judicial Power
}

We have created a Star Wars civilization, with Stone Age emotions, medieval institutions, and godlike technology.

EDWARD O. WILSON

In this book I have endeavoured to understand the right to a fair trial in EU competition law, particularly in relation to attempts to tackle corporate bigness. On a general level, I have inevitably dealt with the exercise of power, the meaning of law within the exercise of power and the individual person. I will address them here in order to conclude this book.

Power - The most difficult profession - The principle of separation of powers is associated with the name of Charles-Louis de Secondat, baron de La Brède et de Montesquieu who argued that every government should have three branches - the legislative, the executive and the judiciary. ${ }^{1}$ The three powers should be separate and should interact in such a way with each other, so that to allow each individual to live in peace with his community:

The political liberty of the subject is a tranquillity of mind arising from the opinion each person has of his safety. In order to have this liberty, it is requisite the government be so constituted as one man need not be afraid of another.

When the legislative and executive powers are united in the same person, or in the same body of magistrates, there can be no liberty; because apprehensions may arise, lest the same monarch or senate should enact tyrannical laws, to execute them in a tyrannical manner.

Again, there is no liberty, if the judiciary power be not separated from the legislative and executive. Were it joined with the legislative, the life and liberty of the subject would be exposed to arbitrary control; for the judge would be then the legislator. Were it joined to the executive power, the judge might behave with violence and oppression.

There would be an end of everything, were the same man or the same body, whether of the nobles or of the people, to exercise those three

1 Montesquieu, Charles de Secondat, Baron de. The Spirit of Laws. New York: Cosimo Classics, 2011. 
powers, that of enacting laws, that of executing the public resolutions, and of trying the causes of individuals. ${ }^{2}$

A contemporary challenge to the principle of separation of powers has been posed by the growth of the executive power and the accompanying process of establishing administrative agencies. Through the process of delegation of power, the legislative establishes new agencies or other types of administrative institutions and invests them with discretionary powers to carry on their mandate. These institutions are often created to operate in technical fields, requiring specialized expertise. In addition, these agencies can be mandated to perform policing and adjudicatory functions to enforce the newly-adopted mandate. This process is called delegation and this, in itself, is an interesting denomination. Since delegation means transferring authority from the holder to the receiver, this implies that the legislative power is the holder and creator - at least temporarily - of the two other powers: bureaucratic-executive and judicial. This denomination is in line with the democratic principles that vest power in the legislative through the voting process.

Within this setup, a question arises concerning the fate of the judicial power. When the legislative branch delegates adjudicatory tasks to executive officials, what shall the judicial branch do? This question is important especially because judges have traditionally been highly trained specialists, undergoing lengthy periods of study and training and held to high standards of ethical behaviour. This is also important because adjudication traditionally took place in courts of law, on the basis of procedural codes and due process rights. Moreover, adjudication produced written decisions available to the public.

The judicial branch has only two choices in this situation. The first choice is to acquiesce and perform what came to be known as administrative control, with deferential judicial review as a type. ${ }^{3}$ The other option - which is not the preferred option in most developed countries - is to engage in in-depth control of the administrative agency performing policing and adjudicatory tasks.

This book examined this question from the point of view of EU competition law enforcement and described the deferential judicial review performed by the CJEU justified by the complexity of the case and the need to safeguard the institutional balance in the Union. Deferential judicial review can be justified using arguments concerning the constitutional design of the Union or the economic expertise that the EU Commission exhibits in competition law cases.

2 Montesquieu, op. cit., pp. 173-174.

3 Gerber, op. cit.Türk, Alexander. "Oversight of Administrative Rulemaking: Judicial Review." European Law Journal 19.1 (2013): pp. 126-142. 
One argument that is sometimes overlooked concerns the litigation style of cases involving economic law matters. In 1910, when Justice White delivered his opinion in Standard Oil, he started by noticing that the case file was "inordinately voluminous, consisting of twenty-three volumes of printed matter, aggregating about twelve thousand pages, containing a vast amount of confusing and conflicting testimony relating to innumerable, complex and varied business transactions, extending over a period of nearly forty years". ${ }^{4}$ Justice White further complained that the bill and exhibits covered one hundred and seventy pages of the printed record. In the same vein, Ramsey has argued that "having realized that they had much to lose at the bar in antitrust proceedings, the Standard Oil team has adopted what would become a prominent strategy in future antitrust litigation - forestalling government action by drowning government attorneys in data and actual findings". 5 (emphasis added)

Still, the existing arguments concerning deferential judicial review in EU competition law do not answer the question about its compatibility with the principle of separation of powers. At its core, this question boils down to whether the judicial branch can choose to adjudicate or not, knowing that choosing to adjudicate against the executive might be criticized as judicial activism and choosing not to adjudicate - that is to defer - might be perceived as a betrayal of the judicial function.

In this respect, the ECtHR positions itself as a clear defender of the judicial function. Its case-law concerning disputes between individual persons and administrative agencies performing adjudicative powers is clear and prescriptive: domestic courts must exercise effective judicial control over the executive in order to comply with the right to a fair trial. The type of dispute, the length of the file, the complexity of the evidence cannot justify deferential judicial review.

In other words, the ECtHR conceives of the judicial function as a monopoly to be exercised by courts or controlled by courts when adjudicative tasks are performed by administrative agencies. The CJEU, on the other hand, conceives of the judicial function as a shared function that can be divided between the executive and the judiciary.

The concomitant exercise of investigative, prosecutorial and adjudicatory powers by the EU Commission in EU competition law and the overtly blunt participation of the political branch in competition policy and enforcement are highly problematic. In the context of the discussion about separation of powers it is interesting to note that there is a solution that can satisfy the

4 Standard Oil Company of New Jersey et Alv. United States, 221 U.S. 1 (1910).

5 Ramsey, op. cit., p. 31. 
standards of fairness of both the ECtHR and the CJEU. This solution would imply a separation of functions within the EU Commission, more precisely the separation of the adjudicatory function from the investigative and prosecutorial tasks. The separation of the adjudicatory function would satisfy both the vision of fairness that perceives the judicial function as a monopoly and the CJEU's vision that the judicial function can be shared. Indeed, a separate division in DG COMP or in the Legal Service can be both independent and, at the same time, remain in the EU Commission.

It is important to highlight that this idea, although discrete, is pursued in some jurisdictions. The ICN has shown in a recent study that a large majority of competition authorities require staff to get involved with the legal analysis of a case without being part of the case team. ${ }^{6}$ This, in fact, could be the beginning of having separate adjudicating units.

Law - genealogy and kinship - The second topic addressed in this book concerned the law on fundamental rights and competition law, its sources and interpretation by the ECtHR and the CJEU.

The works needed for this book were collected and read not based on a predefined bibliography or in the chronological order of their publication. Rather these works were consulted or thoroughly studied based on availability in libraries, recommendations or hunches. This style of reading brought about a realization on the relations that law has with social sciences.

Until recently, the only other social science in the genealogical tree of law was philosophy. It suffices to revert to the works quoted in Chapter 3.1 and one can discern with difficulty the border between law and philosophy, prescription and argumentation. This law-philosophy duo appeared to have been successful, cross-fertilizing and far-reaching.

This situation started to change somewhere in the middle of the last century when academics schooled in both law and economics called for interdisciplinarity and towered a slightly condescending attitude towards the traditional legal scholarship. Richard Posner, a representative of the Chicago School, and himself both a lawyer and an economist, wrote in one of his famous papers that doctrinal analysis views law as largely autonomous in the sense that "its practitioners do not have to know any other field of learning in order to contribute to it". 7 (emphasis added)

6 ICN. Report on Agency Effectiveness Through Organisational Design. Available at: https:// www.internationalcompetitionnetwork.org/wp-content/uploads/2019/ o5/AEWGOrganisational-design-2019-report.pdf accessed on 23 February 2021.

7 Posner, Richard A. “The Present Situation in Legal Scholarship." Yale Law Journal 90.5 (1981): pp. 1113-1130, p. 1114. 
He added that the traditional method of legal analysis was

a humane rather than scientific discipline. As in other humanities, great emphasis is placed on writing well (sometimes on writing impressively - which is not the same thing), footnoting copiously, treating every topic exhaustively, and staying within the linguistic and conceptual parameters of the doctrines analysed. Soundness is valued above originality, thoroughness above brevity; (...). In these respects, doctrinal analysis also resembles appellate legal practice. The writing style, the research interest, the overall approach of the doctrinal analyst are close to those of judges and brief writers and doctrinal analysists move smoothly between academic positions and positions in private practice, in the judiciary, in the governmental legal service, and in legislative and quasi-legislative drafting positions. ${ }^{8}$

Posner continued his quest for "fitting interdisciplinary research in the lawschool mold" in a later paper in which he argued that the decline of faith in law as an autonomous discipline was affected by the breakdown of the political consensus and the "continuing rise in the prestige and authority of scientific and other exact modes of inquiry". 9

Law has become increasingly interdisciplinary, but its relations with other social sciences are analogous to kinship relationships. Indeed, in the last fifty years of the last century law has forged relationships with economics, political science, literature, anthropology, to name just a few. In the field of competition law, interdisciplinarity was inevitable taking into account that in the large majority of developed countries competition agencies employ an almost even number of economists and lawyers. ${ }^{10}$

It can thus be asked if deferential judicial review is a form of resistance to interdisciplinarity. If a case file is based on economic theories or scientific data which the judge is not trained to understand, deferring is not only the wisest, but also the most democratic way of decision-making.

From this vantage point, the difference between the ECtHR and the CJEU is important to grasp. The ECtHR deems deferential judicial review incompatible with the right to a fair trial and stands thus in the camp of the kinship defenders. In essence, the ECtHR argues in favour on interdisciplinarity. The

8 Posner (1981), op. cit., p. 1122.

9 Posner, Richard A. "The Decline of Law as an Autonomous Discipline:1962-1987." Harvard Law Review 100 (1987): pp. 761-78o, p. 772.

10 ICN. Report on Agency Effectiveness Through Organisational Design. Quote above, pp. $45^{-47}$. 
CJEU, on the other hand, defers to the EU Commission generously and appears to be standing firmly in the more protective camp of the genealogy defenders leaving others to deal with interdisciplinary. This categorization joins the class of scholars who defines the relationship between the ECtHR and the CJEU as a relationship of rivalry, at least at the ideological level. ${ }^{11}$

This account can explain why the CJEU is bold when interpreting fundamental rights - which involve a deep consideration of law and its close relative philosophy - but defers on matters that could border speculation, such as theories of harm or the amount of sanctions to be applied in competition cases.

The individual person - Neil Walker noted that the decline of the KeynesianWestphalian frame, "remains, at root, the erosion of a political settlement" which require a realignment of the new points at which power is articulated. ${ }^{12}$ This book has followed the realignment of the political settlement through the emergence of two new points of power in the freshly globalized world, the big businesses and the individual person.

The right to individual petition at the ECtHR has significantly affected procedural participatory rights of individuals in Europe. The progressive enlargement of the field of application of Article 6(1) ECHR meant that individuals could claim having a right to a fair trial in proceedings traditionally considered belonging to public law and, thus, not justiciable. The numbers speak to support this view. Of all the provisions of the ECHR, the right to a fair trial is the most invoked provision and is at the origin of most violations found by the ECtHR. Interestingly, since the adoption of the Charter and of all its provisions, Article 47 which guarantees the right to an effective remedy and a fair trial produces most complaints and is invoked most often by the EU courts.

These numbers indicate that breaches to the right to life or the prohibition against torture are rare in Europe. They speak in favour of healthy democracies and respect of fundamental rights. At the same time, the large number of applications concerning due process - relying on the ECHR or the Charter speak about something more profound. They might reflect the distrust in the justice system generated by the administrative state, the growing presence of the executive in the citizens' life and the diminishing sense of individual agency that accompanies it. These numbers may be the reflection of frustrated citizens who feel that they are not heard in the administrative state and that their interests are not taken into account during the policy-making process.

11 Dawson, Mark. "How Does the European Court of Justice Reason? A Review Essay on the Legal Reasoning of the European Court of Justice." European Law Journal 20.3 (2014): pp. 423-435.

Walker (2008), op. cit., p. 393. 
In this sense, it is interesting to note that the recent protests in France have requested that the Ecole Nationale d'Administration (ENA) be dismantled. France is a well-documented case of how the domestic order interacts with the supranational order. ${ }^{13}$ Lasser followed the legal debates that led to the 2008 constitutional amendment in France introducing for the first time a posteriori constitutional review of legislation on fundamental rights grounds. He found that the rise of judicial review in Europe and the rethinking of the French high courts' procedures in light of Article 6(1) ECHR litigation has had profound effects. He concluded that "the explosive surge of fundamental rights arguments throughout the legal order has drastically reworked the basics of French legal debate; and this stunning argumentative change strongly suggests an important shift in governing mentalities in the direction of more pluralistic and individualistic perspectives".14

In the EU, individuals continue having limited procedural participatory rights. Chalmers argued that this is due to the fact that the EU lacks the statist vision wherein constitutional rights are put in place against transgressions that affect individuals. Instead, the EU has embraced a substitute vision - the vision of the European political economy:

Its fundamental rights, as a reflection of this, can be more managerial, partial and sympathetic to modern market excesses than national counterparts and less attentive to the singularity, vulnerability and potential of human existence. They can also be more attuned to its complexities and the stresses and demands posed for individuals by these market processes. As a consequence, it is unsurprising that there has often been innovation. This is not an argument for disposing with EU fundamental rights but for lowering the expectations and seeing fundamental rights as part of a wider EU legal context, which will inevitably contain much to criticize and much to offer. ${ }^{15}$ (emphasis added)

The "managerial, partial and sympathetic to modern market excesses" fundamental rights might be in tune with the philosophy broadcasted by the NPM movement and its incessant focus on efficiency and avoidance of red

13 The Economist. "Why Emmanuel Macron Wants to Abolish ENA, France's Most Elite College." The Economist. 4 May 2019. Available at: https://www.economist.com/europe/ 2019/05/o4/why-emmanuel-macron-wants-to-abolish-ena-frances-most-elite-college accessed on 23 February 2021.

14 Lasser, op. cit., p. 298.

15 Chalmers, op. cit., p. 39. 
tape ${ }^{16}$ The problem, however, with this view of fundamental rights is that an individual affected by an action of the EU might not be willing to understand what "managerial fundamental rights" imply. In addition, this "managerial" vision of human rights risks spilling over the national understanding of the same rights.

The two visions on fundamental rights in Europe stand in stark contrast, but do not collide. Even if rivalling each other, the ECtHR and the CJEU are not in a race. There is necessarily a relational element in the self-understanding and self-definition of a nonstate entity, "a sense that its normative purpose and its effectiveness alike are dependent on the cultivation of a network of relations with other entities" ${ }^{17}$ It is this relational capital that includes both the ECtHR and the CJEU into the same Pan-European system of fundamental rights protection, characterized by a shared history, a multilingual community and commitment to the same values. This is to say, however, that utmost care should be exercised when dealing with the relational capital between the two supranational courts.

The fact that the CJEU continues to block the accession of the EU to the ECHR and jurisprudential developments in the recent case-law of the CJEU that unmoored effective judicial protection in the EU from the interpretation of Article 6(1) ECHR should be taken seriously. They might diminish the reputational capital of the ECtHR or they might lead the ECtHR to lower the fundamental rights standards it applies. Neither Europe, nor the EU, nor their half a billion citizens need a weak or irrelevant ECtHR. Rather, they need highlycapable and strong supranational courts to contribute solving current challenges, many of which are legal questions.

One such issue is bigness - both corporate and administrative - as a challenge to modern democracies. In light of this, the ECtHR and its case law on due process remains relevant. The ECtHR has consistently defended the right to a fair trial not simply as a human right, but as a democratic principle. Due process requires the separation of powers within the state and the separation of functions within administrative agencies. Due process requires independence of action and independence of decision. Due process requires effective judicial review of administrative discretion. More importantly, however, the ECtHR has defended a version of due process that requires concern both for the individual person, for the executive action and for the judicial function. The individual interests should be assessed during the policy-making process, but also during policy implementation. Also, individual rights should be

16 See Section 2.2. above for a detailed analysis of NPM.

17 Walker (2008), op. cit., p. 381. 
considered when administrative agencies exercise administrative discretion as a form of policing powers. Placing such proceedings in the realm of administrative law and under the expectation that fair trial does not apply might breach the human rights of the individuals affected by these proceedings. What is more serious, however, is that such a situation might erode democracy. As long as the EU practices "managerial" fundamental rights in fields such as EU competition law, the powers of the ECtHR should be safeguarded as the only supranational bastion of procedural participatory rights. 
Cristina Teleki - 9789004447493

Downloaded from Brill.com04/26/2023 08:30:27AM via free access 